\title{
Use of phytoremediation and biochar to remediate heavy metal polluted soils: a review
}

\author{
J. Paz-Ferreiro ${ }^{1,2}$, H. Lu ${ }^{1,3}$, S. Fu ${ }^{1}$, A. Méndez ${ }^{2}$, and G. Gascó ${ }^{2}$ \\ ${ }^{1}$ Key Laboratory of Vegetation Restoration and Management of Degraded Ecosystems, South China Botanical Garden, \\ Chinese Academy of Sciences, Guangzhou 510650, China \\ ${ }^{2}$ Departamento de Edafología, ETSI Agrónomos, Universidad Politécnica de Madrid, Avenida Complutense 3, \\ Madrid 28050, Spain \\ ${ }^{3}$ University of Chinese Academy of Sciences, Beijing 100049, China
}

Correspondence to: J. Paz-Ferreiro (jorge.paz@upm.es)

Received: 12 November 2013 - Published in Solid Earth Discuss.: 25 November 2013

Revised: 9 January 2014 - Accepted: 9 January 2014 - Published: 13 February 2014

\begin{abstract}
Anthropogenic activities are resulting in an increase of the use and extraction of heavy metals. Heavy metals cannot be degraded and hence accumulate in the environment, having the potential to contaminate the food chain. This pollution threatens soil quality, plant survival and human health. The remediation of heavy metals deserves attention, but it is impaired by the cost of these processes. Phytoremediation and biochar are two sound environmental technologies which could be at the forefront to mitigate soil pollution. This review provides an overview of the state of the art of the scientific research on phytoremediation and biochar application to remediate heavy-metalcontaminated soils. Research to date has attempted only in a limited number of occasions to combine both techniques, however we discuss the potential advantages of combining both, and the potential mechanisms involved in the interaction between phytoremediators and biochar. We identified specific research needs to ensure a sustainable use of phytoremediation and biochar as remediation tools.
\end{abstract}

\section{Introduction}

Industrialisation and technical advances have led to an increase in the use of heavy metals and heavy metal pollution. Contrary to organic substances, heavy metals are nondegradable and accumulate in the environment. While some soils can have a high background level of heavy metals due to volcanic activity or weathering of parent materials, in other soils anthropogenic activities, including smelting, mining, use of pesticides, fertilisers and sludges are responsible for these high levels of heavy metals.

Soil heavy metal pollution has a pernicious effect on soil microbial properties (Yang et al., 2012) and on the taxonomic and functional diversity of soils (Vacca et al., 2012). Soil heavy metal pollution poses a risk to the environment and to human health (Roy and McDonald, 2014) due to biomagnification (increases in metal concentration as the element passes from lower to higher trophic levels). Some of these elements can be essential for living organisms while some others are non-essential. Even concentrations of essential elements beyond a certain threshold will have pernicious health effects, as they interfere with the normal metabolism of living systems. It is not the purpose of this article to review the adverse effects of heavy metals on human or plant health. KabataPendias and Pendias (2001) provide a list of toxic effects of heavy metals on plants and the mechanism involved, while a summary of adverse effects of heavy metals on human health was provided by Ali et al. (2013). We would like to remind the reader that studies on heavy metal pollution are focused on $\mathrm{As}, \mathrm{Cd}, \mathrm{Cr}, \mathrm{Hg}$ and $\mathrm{Pb}$ as they are toxic, non-essential heavy metals, and on $\mathrm{Cu}, \mathrm{Ni}$ and $\mathrm{Zn}$ which, although essential, can cause health problems in humans or can result in phytotoxicity at high concentrations.

With an increasing amount of literature on heavy metal remediation, we aim to summarise the state of art of two of these techniques situated at the forefront of remediation practices: phytoremediation, with a focus on phytoextraction, and 
biochar soil amendment, and to discuss their mechanism and how we could combine them to improve remediation efforts.

\section{Biochar}

Biochar is a porous, carbonaceous product obtained from the pyrolysis of organic materials. Numerous materials can be used as feedstocks, including sludges, plant materials and manures. Although the use of charcoal (wood biochar) has been common since preterit times, the idea of using other feedstocks for biochar production is new and relatively unexplored. Typically biochars have high cation exchange capacity and are alkaline. Biochar has many potential benefits on soil properties as an increase in soil biological activity (Lehmann et al., 2011; Paz-Ferreiro et al., 2014), diminishing soil greenhouse gas emissions from agricultural sources and thus enhancing soil carbon sequestration due to its elevated content of recalcitrant forms of carbon (Gascó et al., 2012). The changes brought about by biochar addition to the soil will cause alterations in soil quality (Paz-Ferreiro and $\mathrm{Fu}, 2014)$ with the potential to increase agricultural yields (Jeffery et al., 2011; Liu et al., 2013). The multiple benefits of biochar for soil have been compiled recently in the book by Lehmann and Joseph (2009). However, little information was available in this book about the effect of biochar on soil heavy metals. Although there is a recent review on the role of biochar to remediate polluted soils, with a particular interest in the metalloid arsenic (Beesley et al., 2011), our article has a more focused scope on the combination of phytoremediation and biochar with respect to heavy metal remediation. Moreover, in the last years there have been an increasing number of articles devoted to understanding the interaction between heavy metals, vegetation and biochar.

\section{Mechanism of interaction between biochar and heavy metals}

Biochar characteristics are a function of several factors, including the type of feedstock, the particle size of the feedstock and temperature and conditions of pyrolysis. The wide range of characteristics that biochar might posses makes some particular materials more suitable than others to remediate different heavy metals. Therefore, when selecting a biochar for remediation purposes, scientists should be aware not only of soil type and characteristics but also on biochar properties. Moreover, it should also be considered that key biochar properties such as surface area, $\mathrm{pH}$, ash and carbon contents can be affected by post-treatments and thus enhance biochars' ability to immobilise heavy metals (Lima et al., 2014).

Before reviewing the mechanisms implied in the interaction between biochar and heavy metal it is necessary to note that biochars act on the bioavailable fraction of soil heavy metals and that they can reduce also their leachability.
One of the characteristics of biochars is possessing large surface areas, which implies a high capacity for complex heavy metals on their surface. Surface sorption of heavy metals on biochar has been demonstrated on multiple occasions using scanning electron microscopy (Beesley and Marmiroli, 2011; Lu et al., 2012). This sorption can be due to complexation of the heavy metals with different functional groups present in the biochar, due to the exchange of heavy metals with cations associated with biochar, such as $\mathrm{Ca}^{+2}$ and $\mathrm{Mg}^{+2}$ (Lu et al., 2012), $\mathrm{K}^{+}, \mathrm{Na}^{+}$and $\mathrm{S}$ (Uchimiya et al., 2011c), or due to physical adsorption (Lu et al., 2012). Also oxygen functional groups are known to stabilise heavy metals in the biochar surface, particularly (Uchimiya et al., 2011c) for softer acids like $\mathrm{Pb}^{+2}$ and $\mathrm{Cu}^{+2}$. In addition, Méndez et al. (2009) observed that $\mathrm{Cu}^{+2}$ sorption was related to the elevated oxygenated surface groups and also with high average pore diameter, elevated superficial charge density and $\mathrm{Ca}^{+2}$ and $\mathrm{Mg}^{+2}$ exchange content of biochar. Possibly, sorption mechanisms are highly dependent on soil type and the cations present in both biochar and soil. Some other compounds present in the ash, such as carbonates, phosphates or sulphates (Cao et al., 2009; Karimi et al., 2011; Park et al., 2013) can also help to stabilise heavy metals by precipitation of these compounds with the pollutants.

Alkalinity of biochar can also be partially responsible for the lower concentrations of available heavy metals found in biochar-amended soils. Higher $\mathrm{pH}$ values after biochar addition can result in heavy metal precipitation in soils. Biochar $\mathrm{pH}$ value increases with pyrolysis temperature ( $\mathrm{Wu}$ et al., 2012), which has been associated with a higher proportion of ash content (Cantrell et al., 2012).

Biochar can also reduce the mobility of heavy metals, altering their redox state of those (Choppala et al., 2012). As an example, biochar addition could lead to the transformation of $\mathrm{Cr}^{+6}$ to the less mobile $\mathrm{Cr}^{+3}$ (Choppala et al., 2012).

The relative contribution of the different mechanisms to heavy metal immobilisation by different biochar remains unknown, although some authors like Houben et al. (2013a) postulate that it is mostly a $\mathrm{pH}$ effect.

\section{Studies on the effect of biochar on soil heavy metals}

Table 1 shows a brief summary of the latest papers about the effect of biochar on soil heavy metals. Fellet et al. (2011) tried to use biochar to remediate a multicontaminated mine soil. Biochar addition did not result in the decrease of the total heavy metal content of the soil, however, biochar addition reduced the bioavailability of $\mathrm{Cd}, \mathrm{Pb}$ and $\mathrm{Zn}$ and the mobility (measured using a leaching experiment) of $\mathrm{Cd}, \mathrm{Cr}$ and $\mathrm{Pb}$.

Park et al. (2011) studied the effect of two biochars in a heavy-metal-spiked soil and a naturally strongly polluted soil. They performed a sequential extraction of some heavy metals. They found chicken manure biochar effective reducing extractable concentrations of $\mathrm{Cd}$ and $\mathrm{Pb}$, but not $\mathrm{Cu}$ 
Table 1. Studies considering the effect of biochar application on soil heavy metals. Blank indicates not specified in the article.

\begin{tabular}{|c|c|c|c|}
\hline Feedstock (temperature) & Soil type & Heavy metals & Reference \\
\hline Sewage sludge & Haplic Cambisol & $\mathrm{Cu}, \mathrm{Ni}, \mathrm{Zn}, \mathrm{Cd}, \mathrm{Pb}$ & Méndez et al. (2012) \\
\hline $\begin{array}{l}\text { Rice husk, rice straw and rice } \\
\text { bran }\left(400^{\circ} \mathrm{C}\right)\end{array}$ & Technosol & $\mathrm{As}, \mathrm{Cd}, \mathrm{Pb}, \mathrm{Zn}$ & Zheng et al. (2012) \\
\hline \multirow[t]{2}{*}{ Wastewater sludge $\left(550^{\circ} \mathrm{C}\right)$} & $\begin{array}{l}\text { Chromosol (Australian } \\
\text { system) }\end{array}$ & $\begin{array}{l}\mathrm{As}, \mathrm{Cd}, \mathrm{Cr}, \mathrm{Cu}, \mathrm{Pb}, \\
\mathrm{Ni}, \mathrm{Se}, \mathrm{Zn}, \mathrm{Sb}, \mathrm{B}, \mathrm{Ag} \\
\mathrm{Ba}, \mathrm{Be}, \mathrm{Co}, \mathrm{Sn}, \mathrm{Sr}\end{array}$ & $\begin{array}{l}\text { Hossain et } \\
\text { al. }(2010)\end{array}$ \\
\hline & & $\mathrm{Cu}, \mathrm{Pb}, \mathrm{Zn}$ & Sizmur et al. (2011) \\
\hline $\begin{array}{l}\text { Broiler litter }\left(350 \text { and } 700^{\circ} \mathrm{C}\right) \text {, } \\
\text { pecan shells }\left(450^{\circ} \mathrm{C}\right)\end{array}$ & Abruptic Durixeralfs & $\mathrm{Cu}, \mathrm{Cd}, \mathrm{Ni}$ & Uchimiya et al. (2010) \\
\hline $\begin{array}{l}\text { Pecan shell }\left(450^{\circ} \mathrm{C}\right) \text {, broiler } \\
\text { litter samples }\left(700^{\circ} \mathrm{C}\right)\end{array}$ & $\begin{array}{l}\text { Typic Kandiudult and } \\
\text { Abruptic Durixeralfs }\end{array}$ & $\mathrm{Cu}$ & Uchimiya et al. (2011a) \\
\hline $\begin{array}{l}\text { Chicken manure }\left(550^{\circ} \mathrm{C}\right) \text {, } \\
\text { green waste }\left(550^{\circ} \mathrm{C}\right)\end{array}$ & & $\mathrm{Cd}, \mathrm{Cu}, \mathrm{Pb}$ & Park et al. (2011) \\
\hline $\begin{array}{l}\text { Forest green waste } \\
\left(600-800^{\circ} \mathrm{C}\right)\end{array}$ & Peat & $\mathrm{Cu}$ & Buss et al. (2012) \\
\hline $\begin{array}{l}\text { Dairy manure }(350 \text { and } \\
\left.700^{\circ} \mathrm{C}\right) \text {, } \\
\text { paved feedlot manure }(350 \text { and } \\
\left.700^{\circ} \mathrm{C}\right) \text {, } \\
\text { poultry litter }\left(350 \text { and } 700^{\circ} \mathrm{C}\right) \text {, } \\
\text { turkey litter }\left(350 \text { and } 700^{\circ} \mathrm{C}\right) \text {, } \\
\text { separated swine solids }(350 \text { and } \\
\left.700^{\circ} \mathrm{C}\right)\end{array}$ & Typic Kandiudult & $\mathrm{Pb}, \mathrm{Cu}, \mathrm{Ni}, \mathrm{Cd}$ & Uchimiya et al. (2012a) \\
\hline Mix of hardwoods $\left(400^{\circ} \mathrm{C}\right)$ & & $\mathrm{As}, \mathrm{Cd}, \mathrm{Zn}$ & $\begin{array}{l}\text { Beesley and Marmiroli } \\
\text { (2011) }\end{array}$ \\
\hline Mix of hardwoods $\left(400^{\circ} \mathrm{C}\right)$ & Technosol & $\mathrm{Pb}, \mathrm{Cu}$ & Karami et al. (2011) \\
\hline Orchard prune residue $\left(500^{\circ} \mathrm{C}\right)$ & Technosol & $\begin{array}{l}\mathrm{Cd}, \mathrm{Cr}, \mathrm{Cu}, \mathrm{Ni}, \mathrm{Pb}, \mathrm{Tl}, \\
\mathrm{Zn}\end{array}$ & Fellet et al. (2011) \\
\hline Eucalyptus & & $\mathrm{As}, \mathrm{Cd}, \mathrm{Cu}, \mathrm{Pb}, \mathrm{Zn}$ & Namgay et al. (2010) \\
\hline Wheat straw $\left(350-550^{\circ} \mathrm{C}\right)$ & Technosol & $\mathrm{Cd}$ & Cui et al. (2011) \\
\hline Wheat straw $\left(350-550^{\circ} \mathrm{C}\right)$ & Technosol & $\mathrm{Cd}$ & Cui et al. (2012) \\
\hline Rice straw & Ultisol & $\mathrm{Cu}, \mathrm{Cd}, \mathrm{Pb}$ & Jiang et al. (2012) \\
\hline $\begin{array}{l}\text { Orchard prune residues } \\
\left(500^{\circ} \mathrm{C}\right)\end{array}$ & Technosol & As & Beesley et al. (2013) \\
\hline Miscanthus $\left(600^{\circ} \mathrm{C}\right)$ & & $\mathrm{Cd}, \mathrm{Zn}, \mathrm{Pb}$ & Houben et al. (2013a) \\
\hline $\begin{array}{l}\text { Chicken manure }\left(550^{\circ} \mathrm{C}\right) \text {, } \\
\text { green waste }\left(550^{\circ} \mathrm{C}\right)\end{array}$ & & $\mathrm{Cd}, \mathrm{Pb}$ & Park et al. (2013) \\
\hline $\begin{array}{l}\text { De-inking paper sludge } \\
\left(300 \text { and } 500^{\circ} \mathrm{C}\right)\end{array}$ & Vertisol & $\mathrm{Ni}$ & Méndez et al. (2014) \\
\hline
\end{tabular}


concentration, while green waste biochar was more effective in diminishing all of the heavy metals studied. Heavy metal fractions that were bonded to organic matter increased after biochar addition. Both biochars also decreased $\mathrm{Cd}$ and $\mathrm{Pb}$ presence in soil pore water.

Uchimiya et al. (2012a) analysed the effects on soil heavy meals concentrations of 10 biochars prepared from 5 feedstocks at 2 different temperatures. They observed that manures with a high or low proportion of ash or $\mathrm{P}$ were less effective to immobilise heavy metals. In contrast, biochars prepared at $700{ }^{\circ} \mathrm{C}$ were more effective, which could be attributed to transformations in the material, including the removal of nitrogen containing heteroaromatic and leachable aliphatic functional groups. They found $\mathrm{Cu}$ and $\mathrm{Pb}$ relatively easy to stabilise in soil, while $\mathrm{Cd}$ and $\mathrm{Ni}$ response depended strongly on the type of biochar added to the soil.

Beesley and Marmiroli (2011) detected a retention of As, $\mathrm{Cd}$ and $\mathrm{Zn}$ on biochar surfaces. These authors proved that sorption of the metal was produced at the biochar surface and that this process was not immediately reversible. Leachate concentrations of $\mathrm{Cd}$ and $\mathrm{Zn}$ were reduced 300- and 45-fold, respectively. However, leachate concentrations of As did not diminish.

Namgay et al. (2010) reported that the concentrations of $\mathrm{Cd}$, As and $\mathrm{Pb}$ in maize shoots decreased after biochar application. Beesley et al. (2013) reported interesting results, finding that As can increase in soil pore water after biochar addition, but transfer to the plant be reduced. This would imply that at least some biochars could pose no risk of increasing heavy metals in plants and hence are safe in terms of food chain transfer, but leaching of As to nearby waters must be considered. Karami et al. (2011) added biochar to a mine soil polluted with $\mathrm{Pb}$ and $\mathrm{Cu}$. They found that biochar addition reduced pore water $\mathrm{Pb}$ concentrations to half their values in the mine soil. When biochar was combined with greenwaste compost the levels of $\mathrm{Pb}$ concentrations in the pore water were 20 times lower than in the control. Jiang et al. (2012) found that the acid-soluble fractions of $\mathrm{Pb}^{+2}$ and $\mathrm{Cu}^{+2}$ diminished by $18.8-77.0 \%$ and $19.7-100.0 \%$, respectively, depending on biochar concentration. However, only 5.6-14.1\% of acid-soluble $\mathrm{Cd}^{+2}$ was immobilised. Park et al. (2013) compared the sorption capacity of two biochars, made from chicken manure and from green waste. They found chicken manure biochar more effective to immobilise $\mathrm{Cd}$ and $\mathrm{Pb}$ compared to green waste biochar. Both biochars presented a higher sorption capacity for $\mathrm{Pb}$, possibly as a consequence of precipitation and complexation of $\mathrm{Pb}$ with carbonate, sulphate and phosphate present in the biochar.

Hydrochars could also be used for soil heavy metal immobilisation, however there is a lack of studies on the topic. Hydrochars are produced after pyrolysis of organic-matterrich materials in the presence of subcritical liquid water. This technique can be applied to obtain pyrolysed products from wet feedstocks. In principle, the adsorption capacity of hydrochars seems to be reduced compared to biochars or other adsorbents due to the fewer functional groups containing oxygen present on hydrochar surfaces. However, Xue et al. (2012) have demonstrated experiments that the use of activated hydrochars could overcome these problems. They performed a series of batch and columns experiments to show how this type of hydrochar could reduce $\mathrm{Pb}$ on water. The potential applicability of hydrochar to address soil heavy metal pollution remains untested. However, hydrochars tend to be acidic and could possess phytotoxic or genotoxic risks (Busch et al., 2013), which would deem them unsuitable in restoration projects.

There is a lack of studies concerning how pyrolysis conditions affect biochar properties as heavy metal sorbent. To fill this gap, Uchimiya et al. (2011b) performed an experiment using wood and grass biochars prepared at five different temperatures and another one (Uchimiya et al., 2012b) used poultry litter prepared at four different temperatures to study lead retention. From the first experiment they suggested using biochars prepared at high temperature $\left(650^{\circ} \mathrm{C}\right.$ to $800{ }^{\circ} \mathrm{C}$ ) for remediation purposes. In addition they recommended performing acid or other oxidant post-treatment in order to increase oxygen-containing surface functional groups (carboxyl, carbonyl and hydroxyl) which have a great importance in relation to heavy metal sorption into biochar. In the case of the chicken litter biochar, they found that lower production temperatures were more suitable than higher ones due to the stabilising effect. Higher rates of amendment were necessary in their experiments for chicken manure biochar to get the same remediation effect as plant-derived biochars.

It is expected that as biochar is in contact with soil for a prolonged period of time, oxidation, both biotic and abiotic, would result in the alteration of biochar, a process known as aging. This process, which would result in the formation of carboxylic, phenolic, carbonyl, quinones and hydroxyl functional groups and which can be emulated under laboratory conditions was studied by Uchimiya et al. (2010). These authors found that the immobilisation of heavy metals by biochar was related to the metal lability, this means that heavy metal immobilisation followed the order $\mathrm{Cu}^{+2}>$ $\mathrm{Cd}^{+2}>\mathrm{Ni}^{+2}$. Heavy metal immobilisation was not affected by biochar aging, except for a small increase in $\mathrm{Ni}$ observed in soils with aged biochar.

Earthworms can be added to soil at some stages of ecological restoration due to their well-established positive effects on soil properties as organic matter content, soil formation, soil aeration and nutrient cycling. Sizmur et al. (2011) tested a polluted soil collected in the vicinity of a $\mathrm{Cu}$ mine using biochar in combination with compost and earthworms (Lumbricus terrestris). They found all treatments (biochar alone, biochar + compost, and biochar + compost + earthworms) to reduce the amount of heavy metals compared to the control soils. A limiting aspect when using earthworms with remediation purposes is that their addition to soil could lead to the mobilisation of heavy metals and hence to an increase of plant heavy metal concentrations. Interestingly, Sizmur et 
al. (2011) found that the treatments containing biochar and earthworms did not result in higher heavy metal mobility or plant availability.

As a consequence of heavy metal immobilisation, biochars can reduce the phytotoxicity of polluted soils, resulting in increases in the percentage of germinated seeds and root length (Ahmad et al., 2012).

All of the above experiments have been conducted under laboratory conditions. We would urge scientists to design experiments to help to demonstrate the benefits of biochar against heavy metal pollution under field conditions, as done by Zheng et al. (2012) and Cui et al. (2011, 2012). Zheng et al. (2012) studied the effect of three biochars on different heavy metals (see Table 2) using a multi-polluted soil planted with rice. They found $\mathrm{Cd}, \mathrm{Pb}$ and $\mathrm{Zn}$ to be reduced on rice shoots, in particular when using straw-derived biochar. However, as in rice shoots was increased by biochar addition. More importantly, we believe that this is one of the first studies considering the effects of biochar particle size on plant heavy metals. The authors found that decreases in particle size resulted in less $\mathrm{Cd}, \mathrm{Zn}$ and $\mathrm{Pb}$ accumulating in the rice plants. Similarly, Cui et al. (2011) and Cui et al. (2012) found reduced $\mathrm{Cd}$ uptake in paddy fields and in a soil cropped with wheat, respectively. Both studies consisted of two annual measurements, so the need to reapply biochar after more extended periods of time remains to be explored.

\section{Phytoremediation}

Phytoremediation is an umbrella term for a series of techniques that combine the disciplines of soil microbiology and chemistry and plant physiology (Cunningham and Ow, 1996). Currently the most extended practice for soil heavy metal remediation does not address the problem of contamination, as it consists of encapsulation or digging and dumping. Immobilisation or extraction can be expensive and, as a consequence, phytoremediation can be considered comparatively attractive as it can be used at a relatively low cost to restore or partially decontaminate a site compared to other options, as the cost is $5 \%$ that of other alternative methods (Prasad, 2003). Other advantages would include its good perception as a remediation technique among the general public and being more environmentally friendly than other options, as the introduction of vegetation in the polluted area can also help to prevent erosion or contaminant leaching. Phytoremediation consists in the use of plants to remove contaminants from the environment or to transform them into less harmful forms (see Table 3 for a summary of phytoremediation techniques). Phytoremediation is a relatively new technology, as research studies have been mostly conducted from 1990 onwards.

Phytoextraction is the main and most promising technique to remove soil heavy metals. It is based on the use of hyperaccumulators which uptake heavy metals and then translo- cate them to aboveground tissues (Table 1). One common way of defining a hyperaccumulator is as a plant that can store heavy metals at a level 100-fold greater than common plants without yield reduction (Chaney et al., 2007). On other occasions, these types of plants are defined on their basis to accumulate more than $100 \mathrm{mg} \mathrm{kg}^{-1}$ dry weight of $\mathrm{Cd}$, more than $1000 \mathrm{mg} \mathrm{kg}^{-1}$ of $\mathrm{Cu}, \mathrm{Co}, \mathrm{Cr}$, $\mathrm{Ni}$ or $\mathrm{Pb}$, or more than $10000 \mathrm{~m} \mathrm{~kg}^{-1}$ of Mn or Zn (Baker and Brooks, 1989). Some other authors have mentioned that these values are conservative and propose these criteria to be lowered (van der Ent et al., 2013). Species used for phytoextraction must not only accumulate high amounts of the target element but also have a high growth rate, tolerate the toxic effects of the heavy metals, be adapted to local environment and climate, be resistant to pathogen and pests, be easy to cultivate and repulse herbivores to avoid food chain contamination (Ali et al., 2013).

To date, more than 400 species have been identified as hyperaccumulators, including more than $300 \mathrm{Ni}$ hyperaccumulators ( $\mathrm{Li}$ et al., 2003). In contrast with $\mathrm{Ni}$, only a few plant species have demonstrated the potential to accumulate $\mathrm{Cd}$, $\mathrm{Cu}, \mathrm{Pb}$, and $\mathrm{Zn}$ (Brooks, 1998). Many phytoremediators belong to the taxonomical order of Brassicales and phytoremediators are also abundant in Asterales, Solanales, Poales, Malpighiales, Fabales, Caryophyllales and Rosales (Shao et al., 2011). The amount of metal extracted from the soil depends not only on the plant species utilised but also on the type of soil and climate of the region (Shao et al., 2011).

The mechanism and reasons of phytoaccumulation remain unknown. Metal concentrations are higher in the shoots compared to the roots, suggesting that there could be an ecological role, leading to protection against insect, herbivore or fungal attack, by making the leaves toxic or unpalatable.

Phytoextraction has three main purposes: firstly, to remove the contaminant from the soil or contain it, secondly phytoextraction of elements that have market value and finally gradually improving soil quality to cultivate crops with higher market value (Vangrosveld et al., 2009).

There are a number of problems associated with the effectiveness of this remediation technique. Phytoremediation might not be suitable in areas were the heavy metal concentration is too elevated, as plants could show symptoms of phytotoxicity. In addition, most of the phytoaccumulators have slow growth rate or produce few biomass, limiting the amount of metal uptaken.

Manipulation of soil $\mathrm{pH}$, soil nutrient content or soil organic matter can also be undertaken to improve metal hyperaccumulation. In this sense, these additional agronomic practices can be carried out when heavy metal concentrations in the soil are too elevated to reduce plant stress (Adriano et al., 2004; Gabos et al., 2011; de Abreu et al., 2012). Thus, liming can allow the decrease of the heavy metal available fraction, therefore enabling vegetative growth, while fertilisers can improve phytoextractor growth. On the other hand, both liming and fertiliser addition can alter the mobility 
Table 2. Studies considering the effect of biochar application on soil heavy metals in combination with phytoremediators. Blank indicates not specified in the article.

\begin{tabular}{|c|c|c|c|c|}
\hline Feedstock (temperature) & Soil type & Pollutants & Plant species & Reference \\
\hline Mix of hardwoods $\left(400^{\circ} \mathrm{C}\right)$ & 3 soils & As & Miscanthus $x$ giganteus & Hartley et al. (2009) \\
\hline Miscanthus $\left(600^{\circ} \mathrm{C}\right)$ & & $\mathrm{Cd}, \mathrm{Pb}, \mathrm{Zn}$ & Brassica napus L. & Houben et al. (2013b) \\
\hline $\begin{array}{l}\text { Pruning residues from orchards } \\
\left(550^{\circ} \mathrm{C}\right) \text {, fir tree pellets } \\
\left(350-400^{\circ} \mathrm{C}\right) \text { and manure } \\
\text { pellets mixed with fir tree } \\
\text { pellets }\left(350-400^{\circ} \mathrm{C}\right)\end{array}$ & Technosol & $\begin{array}{l}\mathrm{Cd}, \mathrm{Cr}, \mathrm{Cu}, \mathrm{Fe}, \\
\mathrm{Ni}, \mathrm{Pb}, \mathrm{Tl} \text { and } \\
\mathrm{Zn}\end{array}$ & $\begin{array}{l}\text { Anthyllis vulneraria subsp. } \\
\text { polyphylla (Dc.) Nyman, } \\
\text { Noccaea rotundifolium (L.) } \\
\text { Moench subsp. cepaeifolium } \\
\text { and Poa alpina L. subsp. alpina }\end{array}$ & Fellet et al. (2014) \\
\hline
\end{tabular}

Table 3. Summary of the different techniques of phytoremediation.

\begin{tabular}{ll}
\hline Technique & Description \\
\hline Phytoextraction & $\begin{array}{l}\text { Plants accumulate contaminants in } \\
\text { harvestable biomass i.e., shoots } \\
\text { Phytofiltration }\end{array}$ \\
$\begin{array}{l}\text { Sequestration of pollutants from } \\
\text { contaminated waters by plants }\end{array}$ \\
Phytostabilisation & $\begin{array}{l}\text { Limiting the mobility and bioavailability } \\
\text { of polluting substances by prevention of } \\
\text { migration or immobilisation }\end{array}$ \\
Phytovolatilisation & $\begin{array}{l}\text { Conversion of pollutants to volatile form } \\
\text { followed by their release to the } \\
\text { atmosphere }\end{array}$ \\
Rhizodegradation & $\begin{array}{l}\text { Degradation of organic xenobiotics by } \\
\text { plant enzymes within plant tissues } \\
\text { Degradation of organic xenobiotics in the } \\
\text { rhizosphere by rhizospheric } \\
\text { microorganisms }\end{array}$ \\
Phytodesalination & $\begin{array}{l}\text { Removal of excess salts from saline soils } \\
\text { by halophytes }\end{array}$ \\
\hline
\end{tabular}

and speciation of soil heavy metals. As an example, Li et al. (2012) found that $\mathrm{Cd}$ removal from soil was enhanced by the phytoaccumulator Amaranthus hypocondriacus after NPK or NP fertilisation due to an increase on plant biomass. However, they found that $\mathrm{N}$ alone did not increase plant biomass and led to a limited increment in phytoextraction. Other studies (Huang et al., 2013) have found that P fertilisers can decrease soil $\mathrm{pH}$, enhancing the mobility of $\mathrm{Cd}$ and leading to increased phytoextraction by Sedum alfredii. When adding a phosphate fertiliser to promote phytoremediation, the choice of amendment should be carefully chosen as cations $\left(\mathrm{K}^{+}, \mathrm{Na}^{+}, \mathrm{Ca}^{+2}\right.$ or $\left.\mathrm{NH}_{4}^{+}\right)$associated with the phosphate could affect the mobility of heavy metals (Bolan et al., 2003; Huang et al., 2013). Indeed, plant growth (Oo et al., 2014) and the mobility of different elements in the soil (Ahmad et al., 2013) can be related to soil salinity. For example, Stevens et al. (2003) observed that $\mathrm{Zn}^{+2}$ and $\mathrm{Pb}^{+2}$ mobility increased with the increment of electrical conductivity. Differences in soil $\mathrm{pH}$ caused by the addition of different phos- phate fertilisers can also lead to differences in phytoextraction (Mandal et al., 2012). Urea has also been used to alleviate plant stress and improve $\mathrm{B}$ phytoextraction by the plant species Brassica juncea (Giansoldati et al., 2012).

Organic amendments such as chicken manure have also been shown to increase growth of the species Rorippa globosa (Wei et al., 2011). Chicken manure addition resulted in a decrease in soil extractable $\mathrm{Cd}$ and thus, the concentration of $\mathrm{Cd}$ in the shoots was lower in soils amended with chicken manure than in soils amended with urea or in the controls (soil + phytoremediator). However, the total concentration of metal extracted in the shoots was in both cases higher than in the control. Other materials such as pig manure vermicompost can also be used to improve plant yield and assist phytoremediation, as demonstrated by Wang et al. (2012) in an experiment using Cd as target heavy metal and Sedum alfredii as phytoremediator. Indeed, the use of organic amendments has numerous applications, for example, Siebielec and Chaney (2012) have demonstrated the effectiveness of biosolids compost in the rapid stabilisation of $\mathrm{Pb}$ and $\mathrm{Zn}$ and revegetation of military range contaminated soils increasing tall fescue growth by more than $200 \%$, while Clemente et al. (2012) recovered land contaminated by mining activity with $\mathrm{Cd}, \mathrm{Cu}, \mathrm{Pb}$, and $\mathrm{Zn}$ by a combination of the halophytic shrub Atriplex halimus L. with pig slurry.

The use of chelators such as citric acid or EDTA has also been sometimes advised to assist phytoremediation, with the aim of increasing the mobility of soil heavy metals and thus plant extraction (Zhou et al., 2007; Freitas et al., 2013). However, we should bear in mind that the use of chelators can originate other environmental problems, including toxicity for plants and metal leaching (Zhou et al., 2007).

In addition, experiments should be done to account for the potential impact of climate change on the capability of phytoextractors to accumulate heavy metals, which at the moment is uncertain (Rajkumar et al., 2013).

Finally, we would like to remark that pot experiments are a good first approach to evaluate the potential of a phytoextractor, but they cannot substitute field experiments as the uptake of heavy metals is higher in pots than for the same soil in the 
field (see for example, Marschner, 1986). This can be due to differences in soil moisture or microclimate and to the fact that field-grown plants can reach down to less polluted soil.

Phytostabilisation is another phytoremediation technique and has been used mostly in relation with the stabilisation and containment of mine tailings (Conesa et al., 2007; Méndez et al., 2007). Thus, the vegetative cover diminishes eolian dispersion while roots prevent water erosion and leaching and contributes to the immobilisation of heavy metals. Mechanisms involved in phytostabilisation include precipitation, root sorption, complexation or metal valence reduction. Phytostabilisation, contrary to phytoextraction, primarily focuses on heavy metal sequestration within the rhizosphere but not in plant tissues.

\section{Combining biochar and phytoremediation}

There is an abundance of reports in the literature about amendments, such as lime and compost being used to reduce the bioavailability of heavy metals (Komárek et al., 2013) and thus having the potential to be combined with phytoremediators (de Abreu et al., 2012). Biochar, as reviewed before, can also stabilise heavy metals in soils and thus reduce plant uptake. However, until recently there was a lack of experiments trying to combine both approaches to soil remediation.

Biochar is commonly reported in the literature to increase plant growth, hence there is a potential of biochar to increase the yield of phytoremediators. This increase in plant productivity is highly heterogeneous and has overall been quantified as $10 \%$ (Jeffery et al., 2011; Liu et al., 2013). However, there are several factors that limit the accuracy of the figure provided by Jeffery et al. (2011) and Liu et al. (2013) and that could skew the data. To date, most of the field experiments have been conducted in the short term, being limited to a period of 1-2 $\mathrm{yr}$ and there are a high relative number of laboratory mesocosm incubations (with a duration of 12 months) included in the data set. Also, the data set in this review comprises a higher number of experiments in tropical latitudes compared to temperate ones. Finally, we should bear in mind that a high heterogeneity in the response was detected, depending on the type of soil and plant utilised.

Improvements in plant yield after biochar addition are often attributed to increased water and nutrient retention, improved biological properties and CEC, effects on nutrient cycling and turnover and improvements in soil $\mathrm{pH}$. Many of these effects are interrelated and potentially they could act synergistically. In general, acid soils with a coarse texture or a medium texture are more prone to produce increases in crop productivity (Jeffery et al., 2011; Liu et al., 2013). In the last years the scientific community has also raised awareness over the improvement of plant responses to disease as an additional benefit of biochar soil amendment (Graber et al., 2010). As said before, biochar can alter soil microbial community, possibly including an increase in beneficial organisms that produce antibiotics and can protect plants against pathogens. Another mechanism could be compounds included in biochar such as 2-phenoxyethanol, benzoic acid, hydroxy-propionic and butyric acids, ethylene glycol and quinones suppressing some of the pathogens present in the microbiota (Graber et al., 2010; Elad et al., 2011).

In principle, biochar prepared from any material would have the potential to increase plant yield and thus be used in combination with phytoremediation. However, the use of sewage sludge biochar would be unadvised due to its generally negative effect on crop performance (Jeffery et al., 2011). Caution should also be taken with the presence of heavy metals in sewage sludge biochars, although some studies (Méndez et al., 2012; Hossain et al., 2010) show that the metals present in the biochar are not in mobile forms.

It is also worth mentioning that for a long time, phytoextractors were considered to be non-mycorrhizal. However, in the last year it has been demonstrated that hyperaccumulators can form symbiosis with arbuscular mycorrhizal fungi (AMF) and these enhance plant growth and lead to higher contents of metal extracted (Al Agely et al., 2005; Orlowska et al., 2011). Positive effects of biochar have usually been found in arbuscular mycorrhizal fungi, although exceptions can be found in nutrient-rich soils (Lehmann et al., 2011).

There has been a recent interest about the possibility of combining phytoremediation with other potential plant uses, such as using plants that can be used to obtain bioenergy (de Abreu et al., 2012). While heavy-metal-contaminated areas are not suitable for food production, planting biocrops could promote soil organic matter stocks and reduce soil pollutants (Hartley et al., 2009). Willow and poplar have been commonly used as biocrops and they can be utilised for phytoremediation purposes due to their high uptake of heavy metals and fast growing rates (Baum et al., 2009). Recently, Hartley et al. (2009) observed no increase on As transfer to plants in three soils planted with Miscanthus and amended with hardwood biochar. They warned, however, that alkalyne biochars could mobilise As. It is a well-known fact that As behaves differently to other metals with respect to $\mathrm{pH}$, as As mobility is reduced in acid soils due to adsorption on iron oxide surfaces. The results of Hartley et al. (2009) show that biochar can be used in combination with Miscanthus for phytostabilisation. More recent research has proved that biochar can have an added environmental benefit, improving the greenhouse gas balance of other bioenergy crops such as Miscanthus (Case et al., 2014).

Biochar and phytoremediation techniques have been used recently (see Table 3) to target at Cd-polluted soils (Houben et al., 2013b) using Brassica napus L. as Cd and Zn phytoextractor in combination with Miscanthus biochar and for the case of multicontaminated soils using different biochars and plant species (Fellet et al., 2014). Houben et al. (2013b) observed that phytoextraction of $\mathrm{Cd}$ and $\mathrm{Zn}$ by Brassica napus was impeded by biochar and, due to the lower BCF 


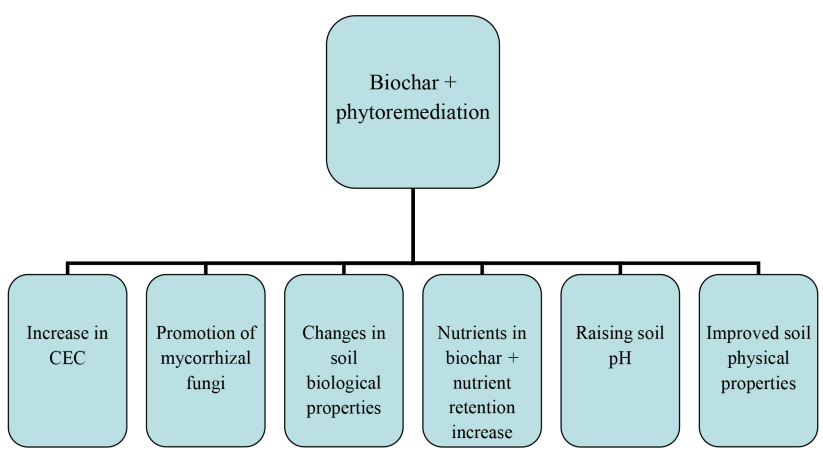

Fig. 1. An overview of the potential positive effects attained by combining phytoremediation and biochar in heavy metal pollution remediation.

achieved in pots with biochar, suggested using biochar and Brassica napus as a phytostabilisation alternative. While Fellet et al. (2014) used three biochars, produced from pruning residues from orchards, fir tree pellets and fir tree pellets mixed with manure at two different doses. Fellet et al. (2014) observed higher concentrations of $\mathrm{Pb}$ in plants grown with the fir tree pellets biochar. However, no increase in yield was obtained with this treatment, and the value of the translocation index, although significantly higher than in the control, was insufficient for the purposes of phytoextraction. Overall, they found the manure biochar to immobilise more heavy metals and also to produce the most noticeable increase in plant biomass, thus, making manure biochar more suitable for phytostabilisation purposes.

It seems plausible that one of the best approaches to combine biochar and phytoextractors would be in multicontaminated soils, where both can target at different elements. Biochar could also be used as a soil conditioner prior to plant colonisation in acidic, polluted mine tailings. However, these two approaches in relation with phytoextraction remains to be tested.

\section{Conclusions and research needs}

Biochar and phytoremediation techniques have the potential to be combined in the remediation on heavy metal polluted soils (see Fig. 1). Biochar can reduce the bioavailability and leachability of heavy metals in the soil. On the other hand phytoextractors can reduce the amount of soil heavy metals in polluted areas.

We anticipate that in the next years there will be a growing interest to study the interaction between phytoremediators and biochars and we identify the next areas as the ones warranting research.

Biochars have highly heterogeneous properties, which should be understood as maximising the efficacy of soil remediation. We should comprehend, firstly, how these properties are relevant for heavy metal adsorption and how they contribute to the different mechanism of heavy metal immobilisation, and secondly how to optimise the choice of pyrolysis conditions and feedstocks in order to produce the desired products.

Most experiments utilising biochar or phytoremediators alone and not in combination have been carried out under laboratory conditions. In the case of phytoremediators this can result in an overestimation of heavy metal extraction.

For biochar most of the experiments (both in field and under laboratory conditions) have been conducted in the short term, which poses an interrogation on the long-term fate of these heavy metals. In fact it could be expected that, due to aging processes, the ability of biochar to sequester heavy metals decreases with time. More research will be needed to understand the aging process in biochar.

Thus, well-designed, large-scale and long-term field trials will be essential to evaluate the feasibility on the approach proposed in this article. The economics of these new remediation processes should be assessed against other options.

Acknowledgements. J. Paz-Ferreiro thanks the Chinese Academy of Sciences for financial support (fellowship for young international scientists number 2012Y1SA0002).

Special Issue: "Environmental benefits of biochar"

Edited by: G. Gascó, A. Méndez, A. M. Tarquis, J. Paz-Ferreiro, and A. Cerdà

\section{References}

Adriano, D. C., Wenzel, W. W., Vangrosveld, J., and Nolam, N. S.: Role of assisted natural remediation in environmental clean-up, Geoderma, 122, 121-142, 2004.

Ahmad, M., Lee, S. S., Yang, J. E., Ro, H. M., Lee, Y. H., and Ok, Y. S.: Effects of soil dilution and amendments (mussel shell, cow bone and biochar) on $\mathrm{Pb}$ availability and phytotoxicity in military shooting range soil, Ecotox. Environ. Safe., 79, 225-231, 2012.

Ahmad, S., Ghafoor, A., Akhtar, M. E., and Khan, M. Z.: Ionic displacement and reclamation of saline-sodic soils using chemical amendments and crop rotation, Land Degrad. Dev., 24, 170-178, 2013.

Al Agely, A., Sylvia, D. M., and Ma, L. Q.: Mycorrhizae increase arsenic uptake by the hyperaccumulator Chinese brake fern (Pteris vittata L.), J. Environ. Qual., 6, 2181-2186, 2005.

Ali, H., Khan, E., and Sajad, M. A.: Phytoremediation of heavy metals - Concepts and applications, Chemosphere, 91, 869-881, 2013.

Baker, A. J. M. and Brooks, R. R.: Terrestrial higher plants which hyperaccumulate metallic elements. A review of their distribution, ecology and phytochemistry, Biorecovery, 1, 81-126, 1989.

Baum, C., Leinweber, P., Weih, M., Lamersdorf, N., and Dimitriou, I.: Effects of short rotation coppice with willows and poplar on soil ecology, Agric. Forestry Res., 3, 183-196, 2009.

Beesley, L. and Marmiroli, M.: The immobilisation and retention of soluble arsenic, cadmium and zinc by biochar, Environ. Pollut., 159, 474-480, 2011. 
Beesley, L., Moreno-Jiménez, E., Gómez-Eyles, J.L., Harris, E., Robinson, B., and Sizmur, T.: A review of biochars' potential role in the remediation, revegetation and restoration of contaminated soils, Environ. Pollut., 159, 3269-3282, 2011.

Beesley, L., Marmiroli, M., Pagano, L., Pigoni, V., Fellet, G., Fresno, T., Vamerali, T., Bandiera, M., and Marmiroli, N.: Biochar addition to an arsenic contaminated soil increases arsenic concentrations in the pore water but reduces uptake to tomato plants (Solanum lycopersicum L.), Sci. Total Environ., 454-455, 598-603, 2013.

Bolan, N. S., Adriano, D. C., and Naidu, R.: Role of phosphorus in (im)mobilization and bioavailability of heavy metals in the soilplant system, Rev. Environ. Contam. T., 177, 1-44, 2003.

Brooks, R. R.: Geobotany and hyperaccumulator, in: Plants that hyperaccumulate heavy metals, their role in phytoremediation, microbiology, archaeology, mineral exploration and phytomining, edited by: Brooks, R. R., Wallingford, UK: CAB, International, 55-94, 1998.

Busch, D., Stark, A., Kammann, C. I., and Glaser, B.: Genotoxic and phytotoxic risk assessment of fresh and treated hydrochar from hydrothermal carbonization compared to biochar from pyrolysis, Ecotox. Environ. Safe., 97, 59-66, 2013.

Buss, W., Kammann, C., and Koyro, H. W.: Biochar reduces copper toxicity in Chenopodium quinoa Willd. in a sandy soil, J. Environ. Qual., 41, 1157-1165, 2012.

Cantrell, K. B., Hunt, P. G., Uchimiya, M., Novak, J. M., and Ro, K. S.: Impact of pyrolysis temperature and manure source on physicochemical characteristics of biochar, Bioresource Technol., 107, 419-428, 2012.

Cao, X. D., Ma, L. N., Gao, B., and Harris, W.: Dairy-manure derived biochar effectively sorbs lead and atrazine, Environ. Sci. Technol., 43, 3285-3291, 2009.

Case, S. D. C., McNamara, N. P., Reay, D. S., and Whitaker, J.: Can biochar reduce soil greenhouse gas emissions from a Miscanthus bioenergy crop?, GCB Bioenergy, 6, 76-89, 2014.

Chaney, R. L., Angle, J. S., Broadhurst, C. L., Peters, C. A., Tappero, R. V., and Sparks, D. L.: Improved understanding of hyperaccumulation yields commercial phytoextraction and phytomining technologies, J. Environ. Qual., 36, 1429-1443, 2007.

Choppala, G. K., Bolan, N. S., Megharaj, M., Chen, Z., and Naidu, R.: The influence of biochar and black carbon on reduction and bioavailability of chromate in soils, J. Environ. Qual., 41, 11751184, 2012.

Clemente, R., Walker, D. J., Pardo, T., Martínez-Fernández, D., and Bernal, M. P.: The use of a halophytic plant species and organic amendments for the remediation of a trace elementscontaminated soil under semi-arid conditions, J. Hazard. Mater., 223-224, 63-71, 2012.

Conesa, H. M., Faz, A., and Arnaldos, R.: Initial studies for the phytostabilization of a mine tailing from the Cartagena-La Unión mining district (SE Spain), Chemosphere, 66, 38-44, 2007.

Cui, L., Li, L., Zhang, A., Pan, G., Bao, D., and Chang, A.: Biochar amendment greatly reduces rice $\mathrm{Cd}$ uptake in a contaminated paddy soil: A two-year field experiment, Bioresources, 6, 26052618, 2011.

Cui, L., Pan, G., Li, L., Yan, J., Zhang, A., Bian, R., and Chang, A.: The reduction of wheat $\mathrm{Cd}$ uptake in contaminated soil via biochar amendment: A two-year field experiment, Bioresources, 7, 5666-5676, 2012.
Cunningham, S. D. and Ow, D. W.: Promises and prospects of root zone of crops phytoremediation, Plant Physiol., 110, 715-719, 1996.

de Abreu, C. A., Coscione, A. R., Pires, A. M., and Paz-Ferreiro, J.: Phytoremediation of a soil contaminated by heavy metals and boron using castor oil plants and organic matter amendments. J. Geochem. Explor., 123, 3-7, 2012.

Elad, Y., Cytryn, E., Meller Harel, Y., Lew, B., and Graber, E. R.: The Biochar effect: Plant resistance to biotic stresses, Phytopathol. Mediterr., 50, 335-349, 2011.

Fellet, G., Marchiol, L., Delle Vedove, G., and Peressotti, A.: Application of biochar on mine tailings: effects and perspectives for land reclamation, Chemosphere, 83, 1262-1297, 2011.

Fellet, G., Marmiroli, M., and Marchiol, L.: Elements uptake by metal accumulator species grown on mine tailings amended with three types of biochar, Sci. Total Environ., 468-469, 598-608, 2014.

Freitas, E. V., Nascimento, C. W., Souza, A., and Silva, F. B.: Citric acid-assisted phytoextraction of lead: A field experiment, Chemosphere, 92, 213-217, 2013.

Gabos, M. B., Casagrande, G., Abreu, C. A., and Paz-Ferreiro, J.: Use of organic matter to mitigate multicontaminated soil and sunflower plants as phytoextractor, R. Bras. Eng. Agric. Ambiental, 15, 1298-1306, 2011.

Gascó, G., Paz-Ferreiro, J. and Méndez, A.: Thermal analysis of soil amended with sewage sludge and biochar from sewage sludge pyrolysis, J. Therm. Anal. Calorim., 108, 769-775, 2012.

Giansoldati, V., Tassi, E., Morelli, E., Gabellieri, E., Pedron, F., and Barbafieri, M.: Nitrogen fertilizer improves boron phytoextraction by Brassica juncea grown in contaminated sediments and alleviates plant stress, Chemosphere, 87, 1119-1125, 2012.

Graber E. R., Meller-Harel, Y., Kolton, M., Cytryn, E., Silber, A., Rav David, D., Tsechansky, L., Borenshtein M., and Elad, Y.: Biochar impact on development and productivity of pepper and tomato grown in fertigated soilless media, Plant Soil, 337, 481496, 2010.

Hartley, W., Dickinson, N. M., Riby, P., and Lepp, N. W.: Arsenic mobility in brownfield soils amended with green waste compost or biochar and planted with Miscanthus, Environ. Pollut., 157, 2654-2662, 2009.

Hossain, M. K., Strezov, V., Chan, K. Y., and Nelson, P. F.: Agronomic properties of wastewater sludge biochar and bioavailability of metals in production of cherry tomato (Lycopersicon esculentum), Chemosphere, 78, 1167-1171, 2010.

Houben, D., Evrard, L., and Sonnet, P.: Mobility, bioavailability and $\mathrm{pH}$-dependent leaching of cadmium,zinc and lead in a contaminated soil amended with biochar, Chemosphere, 92, 1450-1457, 2013a.

Houben, D., Evrard, L., and Sonnet, P.: Beneficial effects of biochar application to contaminated soils on the bioavailability of $\mathrm{Cd}, \mathrm{Pb}$ and $\mathrm{Zn}$ and the biomass production of rapeseed (Brassica napus L.), Biomass Bioenerg., 57, 196-204, 2013 b.

Huang, H., Wang, K., Zhu, Z., Li, Y., He, Z., Yang, X. E., and Gupta, D. K.: Moderate phosphorus application enhances Zn mobility and uptake in hyperaccumulator Sedum alfredii, Environ. Sci. Pollut. R., 20, 2844-2853, 2013.

Jeffery, S., Verheijen, F. G. A., van der Velde, M., and Bastos, A. C.: A quantitative review of the effects of biochar application to soils 
on crop productivity using meta-analysis, Agr. Ecosyst. Environ., 144, 175-187, 2011.

Jiang, J., Xu, R. K., Jiang, T. Y., and Li, Z.: Immobilization of $\mathrm{Cu}(\mathrm{II}), \mathrm{Pb}$ (II) and $\mathrm{Cd}(\mathrm{II})$ by the addition of rice straw derived biochar to a simulated polluted Ultisol, J. Hazard. Mater., 229230, 145-150, 2012.

Kabata-Pendias, A. and Pendias, H.: Trace elements in soil and plants, 3rd Edn., CRC press, 403 pp., 2001.

Karami, N., Clemente, R., Moreno-Jiménez, E., Lepp, N., and Beesley, L.: Efficiency of green waste compost and biochar soil amendments for reducing lead and copper mobility and uptake to ryegrass (Lolium perenne), J. Hazard. Mater., 191, 41-48, 2011.

Komárek, M., Vaněk, A., and Ettler, V.: Chemical stabilization of metals and arsenic in contaminated soils using oxides-a review, Environ. Pollut., 172, 9-22, 2013.

Lehmann, J. and Joseph, S.: Biochar for environmental management: science and technology. Earthscan, London and Sterling, VA USA, 2009

Lehmann, J., Rillig, M. C., Thies, J., Masiello, C. A., Hockaday, W. C., and Crowley, D.: Biochar effects on soil biota. A review, Soil Biol. Biochem., 43, 1812-1836, 2011.

Li, N. Y., Fu, Q. L., Zhuang, P., Guo, B., Zou, B., and Li, Z. A.: Effect of fertilizers on Cd uptake of Amaranthus Hypochondriacus, a high biomass, fast growing and easily cultivated potential Cd hyperaccumulator, Int. J. Phytoremediat., 14, 162-173, 2012.

Li, Y. M., Chaney, R., Brewer, E., Roseberg, R., Angle, J. S., Baker, A., Reeves, R., and Nelkin, J.: Development of a technology for commercial phytoextraction of nickel: economic and technical considerations, Plant Soil, 249, 107-115, 2003.

Lima, I. M., Boykin, D. L., Klasson, K. T., and Uchimiya, M.: Influence of post-treatment strategies on the properties of activated chars from broiler manure, Chemosphere, 95, 96-104, 2014.

Liu, X., Zhang, A., Ji, C., Joseph, S., Bian, R., Li, L., Pan, G., and Paz-Ferreiro, J.: Biochar's effect on crop productivity and the dependence on experimental conditions- a meta-analysis of literature data, Plant Soil, 373, 583-594, 2013.

Lu, H., Zhang, Y. Y., Huang, X., Wang, S., and Qiu, R.: Relative distribution of $\mathrm{Pb}^{2+}$ sorption mechanisms by sludge-derived biochar, Water Res., 46, 854-862, 2012.

Mandal, A., Purakayastha, T. J., Patra, A. K., and Sanyal, S. K.: Phytoremediation of arsenic contaminated soils by Pteris Vittata L. I. Influence of phosphatic fertilizers and repeated harvests, Int. J. Phytoremediat., 14, 978-995, 2012.

Marschner, H.: Mineral nutrition in higher plants, Academic, London, 1986

Méndez, A., Barriga, S., Fidalgo, J. M., and Gascó, G.: Adsorbent materials from paper industry waste materials and their use in $\mathrm{Cu}$ (II) removal from water, J. Hazard. Mater., 165, 736-743, 2009.

Méndez, A., Gómez, A., Paz-Ferreiro, J., and Gascó, G.: Effects of biochar from sewage sludge pyrolysis on Mediterranean agricultural soils, Chemosphere, 89, 1354-1359, 2012.

Méndez, A., Paz-Ferreiro, J., Araujo, F., and Gasco, G.: Biochar from pyrolysis of de-inking paper sludge and its use in the treatment of a nickel polluted soil, J. Anal. Appl. Pyrol., doi:10.1016/j.jaap.2014.02.001, in press, 2014.

Méndez, M. O., Glenn, E. P., and Maier, R. M.: Phytostablization potential of quailbush for mine tailings, J. Environ. Qual., 36, 245-253, 2007.
Namgay, T., Singh, B., and Singh, B. P.: Influence of biochar application to soil on the availability of $\mathrm{As}, \mathrm{Cd}, \mathrm{Cu}, \mathrm{Pb}$, and $\mathrm{Zn}$ to maize (Zea mays L.), J. Aust. Soil Res., 48, 638-647, 2010.

Oo, A. N., Iwai, C. B., and Saenjan, P.: Soil properties and maize growth in saline and nonsaline soils using cassava-industrial waste compost and vermicompost with or without earthworms, Land Degrad. Dev., doi:10.1002/ldr.2208, in press, 2014.

Orlowska, E., Przybylowicz, W., Orlowski, D., Turnau, K., and Mesjasz-Przybylowicz, J.: The effect of mycorrhiza on the growth and elemental composition of Ni hyperaccumulating plant Berkheya coddii Roessler, Environ. Pollut., 159, 37303738, 2011.

Park, J. H., Choppala, G. H., Bolan, N. S., Chung, J. W., and Chuasavathi, T.: Biochar reduces the bioavailability and phytotoxicity of heavy metals, Plant Soil, 348, 439-451, 2011.

Park, J. H., Choppala, G. H., Lee, S. J., Bolan, N., Chung, J. W., and Edraki, M.: Comparative sorption of $\mathrm{Pb}$ and $\mathrm{Cd}$ by biochars and its implication for metal immobilization in soil, Water Air Soil Poll., 224, 1711, doi:10.1007/s11270-013-1711-1, 2013.

Paz-Ferreiro, J. and Fu, S.: Biological indices for soil quality evaluation: perspectives and limitations, Land Degrad. Dev., doi:10.1002/ldr.2262, in press, 2014.

Paz-Ferreiro, J., Fu, S., Méndez, A., and Gasco, G.: Interactive effects of biochar and the earhworm Pontoscolex corethrurus on plant productivity and soil enzymes activities, J. Soils Sediments, doi:10.1007/s11368-013-0806-z, in press, 2014.

Prasad, M. N. V.: Phytoremediation of metal-polluted ecosystems: hype for commercialization, Russ. J. Plant Physiol., 50, 686-700, 2003.

Rajkumar, M., Prasad, M. N. V., Swaminathan, S., and Freitas, H.: Climate change driven plant-metal-microbe interactions, Environ. Int., 53, 74-86, 2013.

Roy, M. and McDonald, L. M.: Metal uptake in plants and health risk assessments in metal-contaminated smelter soils, Land Degrad. Dev., doi:10.1002/ldr.2237, in press, 2014.

Shao, H., Chu, L. Y., Xu, G., Yan, K., Zhang, L. H., and Sun, J. N.: Progress in phytoremediating heavy-metal contaminated soils, in: Detoxification of Heavy Metals, edited by: Sherameti, I. and Varma, A., Springer, 73-90, 2011.

Siebielic, G. and Chaney, R. L.: Testing amendments for remediation of military range contaminated soil, J. Environ. Manage., 108, 8-13, 2012.

Sizmur, T., Wingate, J., Hutchings, T., and Hodson, M. E.: Lumbricus terrestris L. does not impact on the remediation efficiency of compost and biochar amendments, Pedobiologia, 54, S211S216, 2011.

Stevens, D. P., McLaughlin, M. J., and Heinrich, T.: Determining toxicity of lead and zinc runoff in soils: salinity effects on metal partitioning and on phytotoxicity, Environ. Toxicol. Chem., 22, 3017-3024, 2003.

Uchimiya, M., Lima, I. M., Klasson, K. T., and Wartelle, L. H.: Contaminant immobilization and nutrient release by biochar soil amendment: Roles of natural organic matter, Chemosphere, 80, 935-940, 2010.

Uchimiya, M., Klasson, K. T., Wartelle, L. H., and Lima, I. M.: Influence of soil properties on heavy metal sequestration by biochar amendment: 1. Copper sorption isotherms and the release of cations, Chemosphere, 82, 1431-1437, 2011a. 
Uchimiya, M., Wartelle, L. H., Klasson, K. T., Fortier, C. A., and Lima, I. M.: Influence of pyrolysis temperature on biochar property and function as a heavy metal sorbent in soil, J. Agr. Food Chem., 59, 2501-2510, 2011 b.

Uchimiya, M., Chang, S. C., and Klasson, K. T.: Screening biochars for heavy metal retention in soil: Role of oxygen functional groups, J. Hazard. Mater., 190, 432-444, 2011c.

Uchimiya, M., Cantrell, K. B., Hunt, P. G., Novak, J. M., and Chang, S. C.: Retention of heavy metals in a Typic Kandiudult amended with different manure-based biochars, J. Environ. Qual., 41, 1138-1149, 2012a.

Uchimiya, M., Bannon, D. I., Wartelle, L. H., Lima, I. M., and Klasson, K. T.: Lead retention by broiler litter biochars in small arms range soil: Impact of pyrolysis temperature, J. Agr. Food Chem., 60, 5035-5044, 2012b.

Vacca, A., Bianco, M. R., Murolo, M., and Violante, P.: Heavy metals in contaminated soils of the Rio Sitzerri floodplain (Sardinia, Italy): Characterization and impact on pedodiversity, Land Degrad. Dev., 23, 250-364, 2012.

van der Ent, A., Baker, A. J. M., Reeves, R. D., Pollard, A. J., and Schat, H.: Hyperaccumulators of metal and metalloid trace elements: facts and fiction, Plant Soil, 362, 319-334, 2013.

Vangronsveld, J., Herzig, R., Weyens, N., Boulet, J., Adriaensen, K., Ruttens, A., Thewys, T., Vassilev, A., Meers, E., Nehnevajova, E., Van der Lelie, D., and Mench, M.: Phytoremediation of contaminated soils and groundwater: lessons from the field, Environ. Sci. Pollut. R., 16, 765-794, 2009.

Wang, K., Zhang, J., Zhu, Z., Huang, H., Li, T., He, Z., Yang, X., and Alva, A.: Pig manure vermicompost (PMVC) can improve phytoremediation of $\mathrm{Cd}$ and PAHs co-contaminated soil by Sedum alfredii, J. Soils Sediments, 12, 1089-1099, 2012.
Wei, S., Zhu, J., Zhou, Q.X., and Zhan, J.: Fertilizer amendment for improving the phytoextraction of cadmium by a hyperaccumulator Rorippa globosa (Turcz.) Thell. J. Soils Sediments, 11, 915-922, 2011.

Wu, W., Yang, M., Feng, Q., McGrouther, K., Wang, H., Lu, H., and Chen, Y.: Chemical characterization of rice straw-derived biochar for soil amendment, Biomass Bioenerg., 47, 268-276, 2012.

Xue, Y. W., Gao, B., Yao, Y., Inyang, M., Zhang, M., Zimmerman, A. R., and Ro, K. S.: Hydrogen peroxide modification enhances the ability of biochar (hydrochar) produced from hydrothermal carbonization of peanut hull to remove aqueous heavy metals: Batch and column tests, Chem. Eng. J., 200-202, 673-680, 2012.

Yang, D., Zeng, D. H., Li, L. J., and Mao, R.: Chemical and microbial properties in contaminated soils around a magnesite mine in Northeast China, Land Degrad. Dev., 23, 256-262, 2012.

Zheng, R. L., Cai, C., Liang, J. H., Huang, Q., Chen, Z., Huang, Y. Z., Arp, H. P. H, and Sun, G. X.: The effects of biochars from rice residue on the formation of iron plaque and the accumulation of $\mathrm{Cd}, \mathrm{Zn}, \mathrm{Pb}$, As in rice (Oryza sativa $\mathrm{L}$.) seedlings, Chemosphere, 89, 856-863, 2012.

Zhou, Q. X., Cui, S., Wei, S. H., Zhang, W., Cao, L., and Ren, L. P.: Effects of exogenous chelators on phytoavailability and toxicity of $\mathrm{Pb}$ in Zinnia elegans Jacq, J. Hazard. Mater., 146, 341-346, 2007. 